\title{
Finding the Right Approach for a National Underground Infrastructure Register Object
}

\author{
Enrico BOI ${ }^{1}$, Chiara DELL'ORTO ${ }^{2}$, Marco RAFFALDI and Paolo VISKANIC ${ }^{3}$ \\ ${ }^{1}$ Tst Engineering, Cagliari/Italy · eboi@tstengineering.com \\ ${ }^{2}$ Fondazione Lombardia per l'Ambiente, Milan/Italy \\ ${ }^{3}$ R3Gis, Meran/Italy
}

This contribution was double-blind reviewed as extended abstract.

\begin{abstract}
The purpose of this paper is to explain and describe the benefits achieved after a three year pilot project "Progettazione Partecipata dei Sottoservizi nei Territori dei Comuni di Milano, Rho, Pero e Arese" (Participated planning of the underground infrastructure in the area of the municipalities of Milano, Rho, Pero and Arese). The project has been financed by Regione Lombardia, and it has been carried out in partnership with the Italian Association for Trenchless Technology and ANCI Lombardia (National Association of the Local Authorities). The project is also under close observation by the Italian Ministry of Economic Development and AGCOM (National Authority for Communication).
\end{abstract}

\section{Introduction}

In Italy, there is no legislation that uniformly governs aspects related to working activities on below surface underground: the subsoil is often simply considered the space where the infrastructures for transportation, distribution and collection of underground services are located. However, there can be found specific regulations or industry laws that relate to specific aspects of the use and handling of the subsoil. The country lacks a centralized national policy to support actions and interventions in this particular field. The European Union has adopted criteria for fostering the development of local public services by perceiving a strategy that can guarantee that all citizens and all EU companies can benefit from high quality services at accessible prices, but on the other hand no criteria have been defined to better manage the subsoil and subservices. The most important piece of legislation on subsoil is the "INSPIRE Directive" (an acronym for INfrastructure for SPatial InfoRmation in Europe) which entered into force on 15 May 2007. The directive concerns exclusively a uniform coded classification of underground infrastructures within a Geographic Information System on a European Community level. In short, the directive aims, by the use of implementation regulations integrated with European Community provisions, to create a common structure that makes the territorial information of the various states compatible and useable in an international context, overcoming the problems associated with availability, quality, documentation, organization and accessibility of the data. 


\section{Data Acquisition and Representation}

Within the Italian context, Regione Lombardia has been the leading region to deploy a framework attempting to regulate this area with: legislative provisions, technical specifications for survey activities and operating solutions to share, focusing not only on the survey part of the process, but also on the representation of the data in a GIS environment. (cf. AA.VV. 2006, PelagATTI \& NEgRi 2008). Both legal and technical approaches have found application in the "Progettazione Partecipata dei Sottoservizi nei Territori dei Comuni di Milano, Rho, Pero e Arese", a project developed on the area that will play host to the Universal Exposition in 2015.

The aim of the project is to create the best knowledge conditions for designing and deploying the new infrastructures needed in this area, according to criteria of innovation and environmental protection, and ultimately to find the best way to produce a large scale register of underground utilities and infrastructure (see figure 1).

The approach applied on the project has been mostly empirical with evaluations on real activities carried out on site. Key factor of the project has been the extensive use of Trenchless Technologies, like GPR (ground probing radar), on all utility mapping activities (cf. AA.VV. et al. 2007, LUALDI 2007). Finally, the project has assessed economical values and benefits related to the implementation of a large scale register for utility networks.

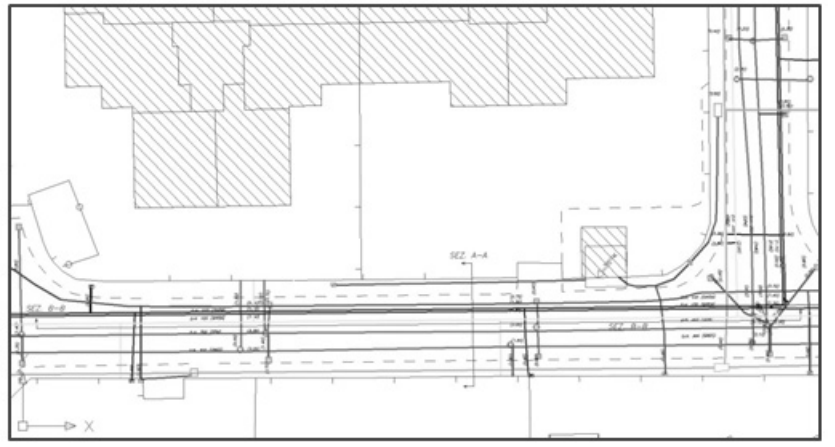

Fig. 1:

Example of Ground

Probing Radar survey

The results of these activities and all information available, from legal aspects to documentation, videos and presentations are published on a public portal (http://www.ors.regione. lombardia.it) and a WebGIS interface to facilitate the display and query of utility network data (see figure 2).

A very important aspect of the project is the representation of the acquired 2D or 3D geographical dataset. The need to represent the positioning of the underground-network infrastructures in a clear and fully understandable way has been one of the aims of this project.

The WebGIS portal was conceived as a virtual area where all stakeholders interacting with Region Lombardy on a daily basis can interact and participate in the implementation of projects through a user-friendly interface. The WebGIS allows navigating in the available data, consulting the characteristics and the associated attribute data. 
Open Geospatial Consortium (OGC) compliant services support interoperability, allowing the user to integrate the data in his own projects. Export functions allow downloading infrastructures in SHP or KML Format. A special section on best practices includes data and tools which are the state of the art in the management of infrastructure networks, and which should serve as an example for new projects.

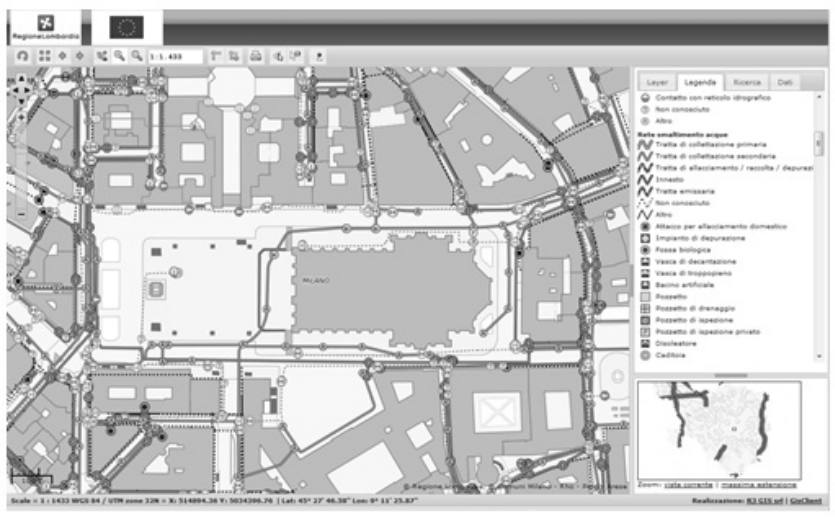

Fig. 2:

2d WebGIS portal (each network has a different mode of representation both in colour and symbology)

\section{Conclusion and Outlook}

This project can be considered the first step towards the creation of a National underground infrastructure register object.

At the national level, taking advantage of the experience made with the project EXPO 2015, active collaborations with ministries and associations of utilities have been initiated for the implementation of a central register of underground, providing benchmarks and standards relevant to the its definition. It is a path that has not yet been exhausted and that will bear fruit if we succeed to convey the view that the services will provide us with the opportunity to realize a new modernity.

\section{References}

A.A.VV. (2006), I Sistemi Informativi Geografici per il governo del territorio in Regione Lombardia. Atti del convegno GeoEsplora - Milano, 9 novembre 2006.

A.A.VV. (2007), Manuale per la posa razionale delle reti tecnologiche del sottosuolo. Edizioni La Tipografica Varese S.p.A.

LuALDI, M. (2007), Atlante dei sistemi geognotecnologiche. Edizioni La Tipografica Varese S.p.A.

Pelagatti, G. \& NegRi, M. (2008), Linee guida per la costruzione del Sistema Informativo Integrato del Sottosuolo. Edizioni La Tipografica Varese S.p.A. 